\title{
Origins, Development, Current Challenges and Future Directions with Activated Prothrombin Complex Concentrate for the Treatment of Patients with Congenital Haemophilia with Inhibitors
}

\author{
Hans H. Brackmann ${ }^{1}$ Wolfgang Schramm² Johannes Oldenburg ${ }^{1} \quad$ Viridiana Cano ${ }^{3}$ Peter L. Turecek ${ }^{4}$ \\ Claude Négrier ${ }^{5}$
}

\footnotetext{
${ }^{1}$ Haemophilia Center, Institute of Experimental Haematology and Blood Transfusion, University of Bonn, Bonn, Germany

2 Rudolf Marx-Stiftung für Hämostaseologie, Universität München and Bluterbetreuung Bayern e. V. (BBB) - Germany

3 Shire International GmbH, a Takeda company, Zürich, Switzerland

${ }^{4}$ Baxalta Innovations GmbH, a Takeda company, Vienna, Austria

${ }^{5}$ Haemophilia and Thrombosis Centre, Louis Pradel Hospital,

University Claude Bernard Lyon 1, Lyon, France
}

Address for correspondence Peter L. Turecek, PhD, Baxalta Innovations GmbH, a Takeda company, DC-Tower, Donau-City-Straße 7, A-1220 Vienna, Austria (e-mail: peter.turecek@takeda.com).

Hämostaseologie 2020;40:606-620.

\begin{abstract}
Keywords

- congenital haemophilia

- inhibitors

- bypassing agents

- FEIBA

- aPCC

Congenital haemophilia A (HA) is caused by deficiency of coagulation factor VIII (FVIII) activity, leading to spontaneous or traumatic bleeding events. While FVIII replacement therapy can treat and prevent bleeds, approximately $30 \%$ of patients with severe HA develop inhibitor antibodies that render FVIII replacement therapy ineffective. The bypassing agents (BPAs), activated prothrombin complex concentrate (aPCC) and recombinant activated FVII, first approved in 1977 and 1996, respectively, act to generate thrombin independent of pathways that involve factors IX and VIII. Both may be used in patients with congenital haemophilia and inhibitors (PwHIs) for the treatment and prevention of acute bleeds and quickly became standard of care. However, individual patients respond differently to different agents. While both agents are approved for on-demand treatment and perioperative management for patients with congenital haemophilia with inhibitors, aPCC is currently the only BPA approved worldwide for prophylaxis in PwHI. Non-factor therapies (NFTs) have a mechanism of action distinct from BPAs and have reported higher efficacy rates as prophylactic regimens. Nonetheless, treatment challenges remain with NFTs, particularly regarding the potential for synergistic action on thrombin generation with concomitant use of other haemostatic agents, such as BPAs, for the treatment of breakthrough bleeds and in perioperative management. Concomitant use of NFTs with other haemostatic agents could increase the risk of adverse events such as thromboembolic events or thrombotic microangiopathy. This review focuses on the origins, development and on-going role of aPCC in the evolving treatment landscape in the management of PwHI.
\end{abstract}

received

February 12, 2020

accepted after revision

April 16, 2020
DOI https://doi.org/

10.1055/a-1159-4273.

ISSN 0720-9355. (c) 2020 Georg Thieme Verlag KG Stuttgart · New York
License terms

(1) (1) 


\section{Introduction}

Congenital haemophilia A (HA) and B (HB) are bleeding disorders characterised by a deficiency of blood clotting factor VIII (FVIII) or factor IX (FIX), respectively. ${ }^{1}$ The type of FVIII/IX mutation present is a major determinant of severity and bleeding tendency. ${ }^{1}$ Severe cases present with bleeding and joint bleeds from early childhood, which, without appropriate treatment and prevention, can result in irreversible joint damage and chronic arthropathy. ${ }^{2}$

Strides have been made in the management of congenital haemophilia over recent decades, including the introduction of plasma-derived and recombinant clotting factor products, use of prophylaxis as standard of care for bleeding prevention, and appropriate surgical management. ${ }^{3-7}$ Such therapy has led to improvements in the health of patients with haemophilia by suppressing the onset of joint damage and arthropathy, preventing life-threatening bleeds, and improving patient quality of life. ${ }^{8,9}$ Nevertheless, treatment challenges remain. First, for patients receiving FVIII/IX products, intravenous infusion is required up to every 2 days for patients with severe $\mathrm{HA}$ and at least twice weekly for those with severe HB. ${ }^{10,11}$ Although high infusion frequency can be reduced with the use of extended half-life products, the frequency can still be burdensome. ${ }^{12}$ Second, treatment can be complicated by the development of alloantibodies (inhibitors) that bind to FVIII or FIX, preventing its haemostatic action. ${ }^{13}$ Such antibodies can neutralise therapeutically administered factor replacement products, and occur in up to 25 to $40 \%$ of severe HA patients, 5 to $15 \%$ of moderate/mild HA patients and 1 to $5 \%$ of patients with severe HB. ${ }^{14}$ Anaphylactic reactions and nephrotic syndrome are also not uncommon in patients with HB and inhibitors. ${ }^{15,16}$

The aetiology of inhibitor development is multifactorial, including both genetic and treatment-related risk factors. ${ }^{17-20}$ Presence of inhibitors is associated with reduced treatment efficacy, increased occurrence of life-threatening bleeds and severe joint damage, which can lead to poor quality of life for patients, family and caregivers; higher morbidity and mortality rates; and increased healthcare costs. ${ }^{21-23}$ Recommended treatment of patients with congenital haemophilia and inhibitors (PwHIs) has focused on eradicating inhibitors using immune tolerance induction (ITI) therapy. ${ }^{3-7,24,25}$ ITI regimens vary and can be used with or without bypassing agents (BPAs) for the treatment of breakthrough bleeding, surgical setting and prophylaxis. ${ }^{7}$

BPAs were developed to 'bypass' the factors blocked by inhibitors, and function by generating thrombin via pathways that do not require activation of FVIII or FIX. ${ }^{26}$ Two BPAs are currently available: activated prothrombin complex concentrate (aPCC, FEIBA [factor eight inhibitor bypass activity]; Takeda, Lexington, Massachusetts, United States) and recombinant activated FVII (rFVIIa, NovoSeven; NovoNordisk, Bagsvaerd, Denmark). Both compounds have been approved for on-demand treatment and perioperative management for PwHIs, while aPCC is the only compound approved worldwide for prophylaxis in PwHI. ${ }^{27-29}$

Both aPCC and rFVIIa have efficacy rates $>80 \%$ in the control of acute bleeding events, with comparable tolerability and low rate of thrombotic complications, as concluded by a Cochrane systematic review. ${ }^{30}$ The choice of BPA for on-demand treatment may be driven by several factors, including burden of the infusion due to volume and infusion time, experience of treater and/or patient preference. ${ }^{26}$ Furthermore, individuals may show a better response to one agent over another, as reflected in the FEIBA NovoSeven Comparative (FENOC) study, ${ }^{31}$ in which $32 \%$ of patients reported efficacy for either aPCC or rFVIIa at 6 hours post-treatment. ${ }^{31}$ Achievement of good haemostatic efficacy within the first few hours of a bleed can reduce the risk of cartilage destruction; therefore, selection of the most appropriate BPA for each individual is important. $^{31}$

Treatments with different mechanisms of action that aim to address the challenges of treating PwHI are in development. Here, we review the role of aPCC in an evolving treatment landscape for patients with congenital HA with inhibitors.

\section{Development of Activated Prothrombin Complex Concentrate}

The clinical use of prothrombin complex concentrates (PCCs) was extended early beyond their basic use as a substitution therapy for patients with prothrombin complex protein deficiencies, particularly for those with a FIX deficiency (HB), to the treatment of those with inhibitory antibodies against FVIII and FIX. However, the clinical use of PCCs remained a niche indication for many years. Only six treatment episodes were reported until $1977 . .^{32-35}$ For a long time, the clinical success of PCCs in the management of patients with inhibitors was attributed to the activated prothrombin complex enzyme in addition to the zymogen content of the concentrates. ${ }^{36}$ Therefore, in the early 1970s, the so-called auto-FIX concentrates were developed as a new therapeutic approach for treating HA patients with inhibitors. ${ }^{37}$ The independent development of commercial aPCCs began around 1970 by two laboratories in parallel: Hyland Laboratories in the United States developing anti-inhibitor coagulant complex (Autoplex) and Immuno AG in Austria developing aPCC (FEIBA), the latter of which became the mainstay of treatment for patients with inhibitors.

aPCC is a plasma-derived, vapour-heated and nano-filtered ( $35 \mathrm{nM}$ ) concentrate of primarily vitamin K-dependent clotting factors (FII, FVII, FIX and FX) in both their zymogen and active forms ( - Table 1 ) that is proposed to act at cellular surfaces near the site of injury. ${ }^{38}$ It has been commercially available since 1977 to bypass the need for FVIII and FIX and to control and prevent bleeding in PwHI. ${ }^{39}$ It is approved in over 80 countries and is indicated for control of spontaneous bleeds, perioperative management and routine prophylaxis for patients with congenital HA or HB with inhibitors and for the treatment of spontaneous bleeds and perioperative management for patients with acquired HA. Please note that indications do vary by country. ${ }^{27,40}$

The mechanism of action of aPCC is multi-site and involves three main steps (-Fig. 1). ${ }^{41}$ First, FII-FXa complex triggers immediate thrombin generation (TG) on the 
Table 1 Haemostatic components of aPCC

\begin{tabular}{|l|l|}
\hline & Units per $1 \mathrm{U}$ of FEIBA $^{\mathrm{a}}$ \\
\hline Prothrombin (factor II) & $1.3 \pm 0.3$ \\
\hline Thrombin & $0.01 \pm 0.004$ \\
\hline Factor VII & $0.9 \pm 0.1$ \\
\hline Factor VIIla & $1.5 \pm 0.2$ \\
\hline Factor IX & $1.4 \pm 0.1$ \\
\hline Factor IXa & approx. 0.0006 \\
\hline Factor X & $1.1 \pm 0.2$ \\
\hline Factor Xa & $0.06 \pm 0.002$ \\
\hline Factor VIII & $0.03-0.1$ \\
\hline Factor V & approx. 0.6 \\
\hline Protein C & $1.1 \pm 0.2$ \\
\hline Protein S & approx. 0.4 \\
\hline
\end{tabular}

Note: Activated prothrombin complex concentrate (aPCC) composition based on data obtained during the release procedure of aPCC and measured in the research laboratories at Baxter as described in the methods. ${ }^{41,58}$

${ }^{\mathrm{a}}$ One unit of factor eight inhibitor bypass activity (FEIBA) is defined as the amount of FEIBA capable of shortening the clotting time of hightitre FVIII inhibitor plasma by $50 \%$.

membrane surface of tissue-factor-bearing cells and activated platelets, bypassing the haemostatic cascade and prompting initial fibrin clot formation. In addition, thrombinmediated feedback reactions lead to activation of other coagulant components and to further platelet activation. Second, endogenous anti-tissue factor pathway inhibitors slow down the reactions on tissue-factor-bearing cells. Zymogen and procoagulant enzyme components of aPCC directly and indirectly amplify TG on activated platelet surfaces

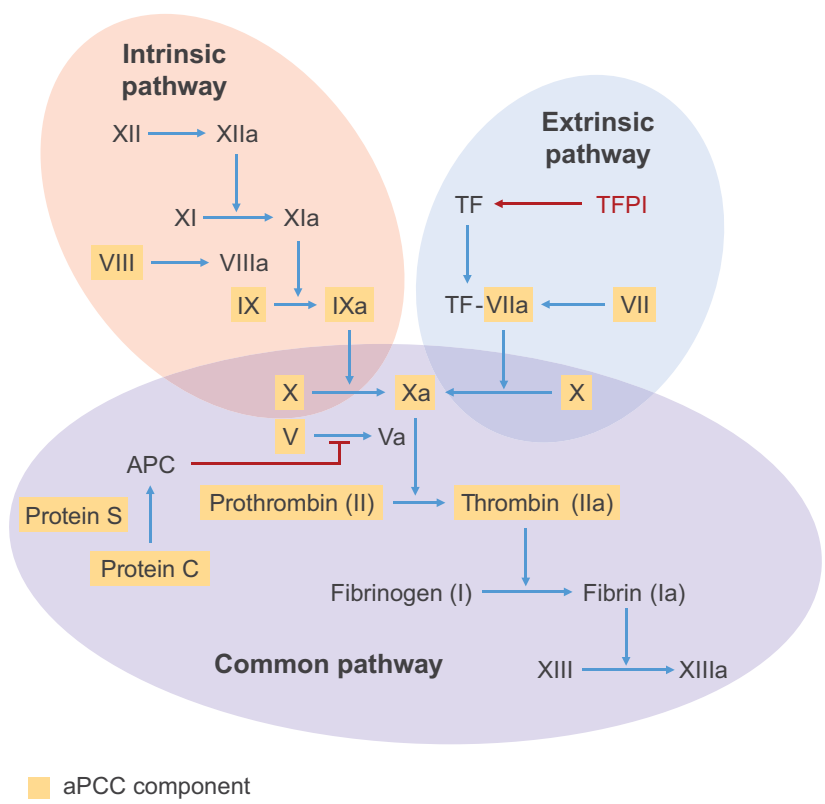

Fig. 1 Mechanism of action for activated prothrombin complex concentrate (aPCC). APC, activated protein C; TF, tissue factor; TFPI, tissue factor pathway inhibitor. resulting in a burst of thrombin. Due to the long half-life of the zymogens, circulating substrate levels are elevated, leading to long-lasting haemostasis that prevents the recurrence of bleeds. Third, aPCC contains the natural clotting inhibitors protein $\mathrm{C}$ and protein $\mathrm{S} .{ }^{41} \mathrm{~A}$ balanced increase in these factors down-regulates coagulation and, thus, might help to prevent thrombotic effects in absence of another procoagulant trigger. ${ }^{38,42}$

\section{aPCC in the Management of PwHI}

aPCC has demonstrated control of bleeding episodes in clinical trials and in over 40 years of real-world usage in patients with congenital and acquired haemophilia with FVIII or FIX inhibitors across a range of ages, from toddlers to elderly patients, and in different clinical settings as on demand, ${ }^{31,43-46}$ surgical, ${ }^{45,47,48}$ prophylactic ${ }^{28,44,49-51}$ and concomitant with ITI therapy. ${ }^{52-56} \mathrm{~A}$ post-authorisation safety study of PwHI receiving aPCC as prophylaxis or as on-demand treatment reported the occurrence of 3 treatment-related serious adverse events (AEs) in 3 (3.7\%) patients and 6 treatment-related non-serious AEs in 5 patients (6.2\%). One deep vein thrombosis was reported in an elderly patient; no other reports of thromboembolic events (TEEs) or thrombotic microangiopathy (TMAs). ${ }^{28} \mathrm{~A}$ meta-analysis of studies in PwHIs reported no TEEs with long-term aPCC prophylaxis or under ITI regimen. ${ }^{57}$ In this study, the incidence rate of TEEs for on-demand therapy was 5.09 (95\% confidence interval [CI]: 0.01-1,795.6) per 100,000 infusions, and the pooled TEE incidence rate in congenital haemophilia patients was $<0.01$ per 100,000 infusions. ${ }^{57}$ No TMAs have been reported with the use of aPCC as monotherapy to date. ${ }^{48,58}$ Key clinical and real-world observational studies with aPCC are summarised in - Table 2 .

In line with the current approach to treatment, the Future of Immunotolerance Treatment (FIT) group recommends that all patients with inhibitors should be offered at least one attempt of ITI while under prophylaxis, using the existing management algorithm. ${ }^{25}$ The group has proposed a hypothetical approach including non-factor therapies (NFTs), but recommends that prospective clinical studies are conducted to further explore the effect of combining these agents with FVIII in ITI. ${ }^{25}$ As patients with inhibitors have a higher potential for bleeding-related death ${ }^{23}$ and additional daily burden, ${ }^{59}$ all patients should be given the opportunity to eradicate inhibitors as it is the only proven regimen to restore patient response to FVIII, which is the fundamental deficiency. aPCC is part of the original 'Bonn Protocol', first conceived in the 1970s in Bonn, Germany, by Dr Hans-Hermann Brackmann for bleeding prevention during ITI. ${ }^{54}$ The original protocol includes $100 \mathrm{IU}$ FVIII $/ \mathrm{kg}$ body weight and $50 \mathrm{U}$ aPCC$/ \mathrm{kg}$ body weight twice daily until the inhibitor titre decreased to $<1 \mathrm{BU} .{ }^{54}$ Proposed molecular mechanisms of ITI include T-cell exhaustion/anergy, inhibition of FVIII-specific memory B cell differentiation, formation of anti-idiotypic antibodies and, more recently, the generation of FVIII-specific regulatory T cells. ${ }^{60,61}$ rFVIIa is often regarded as the preferred substance for treatment of 
Table 2 Summary of aPCC clinical and real-world studies in PwHI

\begin{tabular}{|c|c|c|c|c|c|c|c|}
\hline $\begin{array}{l}\text { Reference } \\
\text { (first author } \\
\text { and year) }\end{array}$ & $\begin{array}{l}\text { Study } \\
\text { name }\end{array}$ & Study design & Inclusion criteria & $N$ & Regimen/dose & $\begin{array}{l}\text { Duration of } \\
\text { treatment }\end{array}$ & Outcome \\
\hline $\begin{array}{l}\text { Brackmann } \\
1977^{53}\end{array}$ & - & Case study & $\begin{array}{l}\text { Patient with HA } \\
\text { with inhibitors }\end{array}$ & 1 & $\begin{array}{l}\text { ITI: initial } 3,000 \mathrm{U} \\
\text { FVIII }+2,500 \mathrm{U} \text { FIX } \\
\text { daily, rising to } \\
12,000 \mathrm{UVVIII} \\
\text { daily for } 10 \mathrm{~d} \text {, then } \\
\text { gradual reduc- } \\
\text { tions over } 7 \text { mo to } \\
3,000 \mathrm{U} \\
\text { FVIII }+1,000 \mathrm{FIX} \\
\text { (aPCC) }\end{array}$ & $7 \mathrm{mo}$ & $\begin{array}{l}\text { No demonstrable } \\
\text { inhibitor after } 7 \mathrm{mo} \\
\text { of treatment }\end{array}$ \\
\hline $\begin{array}{l}\text { Sjamsoedin } \\
1981^{120}\end{array}$ & - & $\begin{array}{l}\text { Randomised, } \\
\text { double-blind, } \\
\text { clinical }\end{array}$ & $\begin{array}{l}\text { Patients with HA } \\
\text { with inhibitors }\end{array}$ & 15 & $\begin{array}{l}\text { On demand: } 88 \\
\text { U/kg aPCC after } \\
\text { bleed or pro- } \\
\text { thrombin complex } \\
\text { concentrate; then } \\
\text { post } 12 \text { h for } \\
\text { muscle bleed or } \\
\text { post } 6 \mathrm{~h} \text { for } \\
\text { mucocutaneous } \\
\text { bleed, if necessary }\end{array}$ & $24 \mathrm{~h}$ & $\begin{array}{l}\text { aPCC judged as } \\
\text { 'effective' in } 64 \% \\
\text { episodes; control } \\
\text { judged as 'effec- } \\
\text { tive' in } 52 \% \text { epi- } \\
\text { sodes. Bleeding in } \\
\text { the same joint and } \\
\text { joint mobility } \\
\text { significantly } \\
\text { improved with } \\
\text { aPCC vs. control } \\
(p=0.0085 \text { and } \\
p=0.006, \\
\text { respectively) }\end{array}$ \\
\hline $\begin{array}{l}\text { Hilgartner } \\
1983^{43}\end{array}$ & - & Open-label & $\begin{array}{l}\text { Patients with } \mathrm{HA} \\
\text { or } \mathrm{HB} \text { and inhibi- } \\
\text { tors aged } \geq 4 \mathrm{y}\end{array}$ & $\begin{array}{l}49(46 \mathrm{HA} ; \\
3 \mathrm{HB})\end{array}$ & $\begin{array}{l}\text { On demand: } \\
50-70 \mathrm{U} / \mathrm{kg} \text { aPCC } \\
\text { at } 12-\mathrm{h} \text { intervals }\end{array}$ & $72 \mathrm{~h}$ & $\begin{array}{l}93 \% \text { of } 165 \text { bleed- } \\
\text { ing episodes } \\
\text { in joints ( } 102 \\
\text { episodes), mucous } \\
\text { membranes ( } 20 \\
\text { episodes), muscle } \\
\text { and soft tissue ( } 33 \\
\text { episodes), emer- } \\
\text { gency episodes ( } 10 \\
\text { episodes; } 3 \text { CNS } \\
\text { bleeds and } 4 \text { surgi- } \\
\text { cal procedures) } \\
\text { were controlled. } \\
36 \% \text { were con- } \\
\text { trolled with } 1 \text { infu- } \\
\text { sion in } 12 \mathrm{~h}, 42 \% \text { by } \\
\geq 1 \text { infusions in } \\
36 \mathrm{~h} \text { and } 14 \% \text { in } \\
>36 \text { h. No serious } \\
\text { side effects }\end{array}$ \\
\hline $\begin{array}{l}\text { Hilgartner } \\
1990^{121}\end{array}$ & - & $\begin{array}{l}\text { Uncontrolled; } \\
\text { compared with } \\
\text { earlier aPCC study }\end{array}$ & $\begin{array}{l}\text { Patients with HA } \\
\text { and inhibitors }\end{array}$ & $\begin{array}{l}41 \text { ( } 106 \\
\text { bleeding } \\
\text { episodes) }\end{array}$ & $\begin{array}{l}\text { On demand: va- } \\
\text { pour-heated aPCC; } \\
50 \mathrm{U} / \mathrm{kg} \text { for mucus } \\
\text { membrane bleeds, } \\
75 \mathrm{U} / \mathrm{kg} \text { for joint } \\
\text { and muscle } \\
\text { haemorrhages }\end{array}$ & Maximum: $36 \mathrm{~h}$ & $\begin{array}{l}88 \% \text { episodes were } \\
\text { controlled, } 79 \% \\
\text { within } 36 \mathrm{~h}\end{array}$ \\
\hline $\begin{array}{l}\text { Brackmann } \\
1996^{54}\end{array}$ & - & $\begin{array}{l}\text { Retrospective } \\
\text { study }\end{array}$ & $\begin{array}{l}\text { Patients with HA } \\
\text { and inhibitors } \\
\text { undergoing ITI }\end{array}$ & 81 & $\begin{array}{l}\text { Prophylaxis under } \\
\text { ITI: } 100-150 \mathrm{IU} / \mathrm{kg} \\
\text { FVIII }+50 \mathrm{U} / \mathrm{kg} \\
\text { aPCC } 2 \times \text { daily un- } \\
\text { til }<1 \mathrm{BU} \text {, then } \\
150 \mathrm{IU} / \mathrm{kg} \text { FVIII } \\
2 \times \text { daily }\end{array}$ & Mean: 10-15 mo & $\begin{array}{l}\text { For } 22 \text { patients } \\
\text { with high respond- } \\
\text { ing inhibitors, time } \\
\text { to }<1 \text { BU was } 7 \text { mo, } \\
\text { and time to FVIII } \\
\text { normalisation was } \\
14.5 \text { mo. For } 15 \\
\text { moderate respond- } \\
\text { ers, time to }<1 \mathrm{BU} \\
\text { was } 2.4 \text { mo, and } \\
\text { time to FVIII nor- } \\
\text { malisation was } \\
10.7 \text { mo }\end{array}$ \\
\hline $\begin{array}{l}\text { Négrier } \\
1997^{63}\end{array}$ & - & $\begin{array}{l}\text { Multicentre retro- } \\
\text { spective study }\end{array}$ & $\begin{array}{l}\text { Patients with } \mathrm{HA} \\
\text { or } \mathrm{HB} \text { with inhibi- } \\
\text { tors receiving } \\
\text { aPCC }\end{array}$ & 60 & $\begin{array}{l}\text { Prophylaxis: } \\
65-510 \mathrm{U} / \mathrm{kg} / \mathrm{d} \\
\text { aPCC, typically as } \\
65-100 \mathrm{U} / \mathrm{kg} \\
\text { every } 6-12 \mathrm{~h}\end{array}$ & NA & $\begin{array}{l}\text { Efficacy was } \\
\text { judged as 'good or } \\
\text { excellent' in } 81.3 \% \\
\text { of episodes. Toler- } \\
\text { ance was assessed } \\
\text { as 'good' in } 98.8 \% \\
\text { of episodes }\end{array}$ \\
\hline
\end{tabular}


Table 2 (Continued)

\begin{tabular}{|c|c|c|c|c|c|c|c|}
\hline $\begin{array}{l}\text { Reference } \\
\text { (first author } \\
\text { and year) }\end{array}$ & $\begin{array}{l}\text { Study } \\
\text { name }\end{array}$ & Study design & Inclusion criteria & $\mathrm{N}$ & Regimen/dose & $\begin{array}{l}\text { Duration of } \\
\text { treatment }\end{array}$ & Outcome \\
\hline $\begin{array}{l}\text { Oldenburg } \\
1999^{52}\end{array}$ & - & Open-label & $\begin{array}{l}\text { Patients with HA } \\
\text { and inhibitors un- } \\
\text { dergoing ITI }\end{array}$ & 60 & $\begin{array}{l}\text { Prophylaxis under } \\
\text { ITI: } 100 \mathrm{IU} / \mathrm{kg} \\
\text { FVIII }+50 \mathrm{U} / \mathrm{kg} \\
\text { aPCC } 2 \times \text { daily } \\
\text { until <1 BU; } \\
150 \text { IU } / \mathrm{kg} \text { FVIII } \\
2 \times \text { daily until no } \\
\text { inhibitor detected } \\
\text { and FVIII half-life } \\
\text { normalised }\end{array}$ & $\begin{array}{l}\text { Median (range) } \\
\text { time to < } 1 \mathrm{BU}: 5.4 \\
(0.2-97.3) \mathrm{mo} \text {; to } \\
\text { FVIII half-life nor- } \\
\text { malisation: } 14.1 \\
(1.8-103.2) \text { mo }\end{array}$ & $\begin{array}{l}\text { Successful immune } \\
\text { tolerance was } \\
\text { achieved in } 52 \\
\text { patients ( } 86.7 \%) ; \\
\text { therapy failed in } 8 \\
\text { patients ( } 13.3 \%) \text {. } \\
\text { The immune toler- } \\
\text { ance achieved was } \\
\text { long-lasting in all } 52 \\
\text { patients, with no in- } \\
\text { hibitor relapse in up } \\
\text { to } 20 \text { y of follow-up }\end{array}$ \\
\hline $\begin{array}{l}\text { Ehrlich } \\
2002^{122}\end{array}$ & - & $\begin{array}{l}10-y \text { pharmacovi- } \\
\text { gilance (all spon- } \\
\text { taneously } \\
\text { reported throm- } \\
\text { botic AEs) }\end{array}$ & $\begin{array}{l}\text { Patients with } \\
\text { inhibitors } \\
\text { receiving aPCC }\end{array}$ & - & $\begin{array}{l}\text { Safety: equivalent } \\
\text { to } 3.95 \times 10^{5} \text { typ- } \\
\text { ical infusions dis- } \\
\text { tributed } \\
\text { worldwide }\end{array}$ & - & $\begin{array}{l}16 \text { AEs docu- } \\
\text { mented over } 10-y \\
\text { period (incidence } \\
\text { of } 4.05 \text { per } 10^{5} \\
\text { infusions). DIC } \\
(n=7) \text { and myo- } \\
\text { cardial infarction } \\
(n=5) \text { were the } \\
\text { most frequent. } \\
\text { One fatality in an } \\
87-y \text {-old metastatic } \\
\text { cancer patient. In } \\
13 / 16 \text { ( } 81 \%) \\
\text { patients, known } \\
\text { risk factors were } \\
\text { present (overdose, } \\
\text { obesity, serum lip- } \\
\text { id abnormalities) }\end{array}$ \\
\hline Bui $2002^{123}$ & - & Case study & $\begin{array}{l}\text { Post-surgical pa- } \\
\text { tient supported by } \\
\text { ECMO treated } \\
\text { with rFVIla, then } \\
\text { switched to aPCC }\end{array}$ & 1 & $\begin{array}{l}\text { Post-surgery on } \\
\text { demand: rFVIla: } \\
7.8 \mathrm{mg}(90 \mu \mathrm{g} / \mathrm{kg}) \\
\text { then } 4.8 \mathrm{mg} . \mathrm{aPCC} \\
\text { dose not recorded }\end{array}$ & NA & $\begin{array}{l}\text { Patient died } 20 \text { min } \\
\text { after aPCC treat- } \\
\text { ment due to aPCC- } \\
\text { precipitated } \\
\text { thrombosis; clots } \\
\text { were noted in the } \\
\text { ECMO tubing }\end{array}$ \\
\hline $\begin{array}{l}\text { Rosenfeld } \\
2002^{124}\end{array}$ & - & Case study & $\begin{array}{l}\text { Patients with se- } \\
\text { vere HA and } \\
\text { inhibitors receiv- } \\
\text { ing prolonged se- } \\
\text { quential aPCC and } \\
\text { rFVlla }\end{array}$ & 1 & $\begin{array}{l}\text { On demand: aPCC } \\
75 \mathrm{U} / \mathrm{kg} \text { daily for } 2 \\
\mathrm{~d} \text { then every } 12 \mathrm{~h} \\
\text { for } 1 \mathrm{~d} \text {; then rFVIla } \\
90 \mu \mathrm{g} / \mathrm{kg} \text { every } 2 \mathrm{~h} \\
\text { for } 2 \mathrm{~d} \text { then every } \\
6 \mathrm{~h} \text { for } 2 \mathrm{~d} \text {; then } \\
\text { aPCC } 75 \mathrm{U} / \mathrm{kg} \text { ev- } \\
\text { ery } 12 \mathrm{~h}\end{array}$ & $14 \mathrm{~d}$ & $\begin{array}{l}\text { Patient developed } \\
\text { pulmonary embo- } \\
\text { lism after sequen- } \\
\text { tial therapy }\end{array}$ \\
\hline $\begin{array}{l}\text { Dimichele } \\
2006^{48}\end{array}$ & - & $\begin{array}{l}\text { Post-marketing } \\
\text { surveillance study }\end{array}$ & $\begin{array}{l}\text { Patients with HA } \\
\text { and inhibitors re- } \\
\text { ceiving aPCC }\end{array}$ & 63 & NA & NA & $\begin{array}{l}>4,500 \text { infusions in } \\
204 \text { treatment } \\
\text { courses in } 63 \\
\text { patients. The inci- } \\
\text { dence of AEs was } \\
\text { low (<0.04\%). No } \\
\text { thrombotic com- } \\
\text { plications were } \\
\text { reported. Efficacy } \\
\text { was considered } \\
\text { good or excellent } \\
\text { in } 82 \% \text { of acute } \\
\text { treatments and } \\
91 \% \text { of surgeries }\end{array}$ \\
\hline $\begin{array}{l}\text { Astermark } \\
2007^{31}\end{array}$ & FENOC & $\begin{array}{l}\text { Head-to-head, } \\
\text { open-label, cross- } \\
\text { over equivalency } \\
\text { study of aPCC vs. } \\
\text { rFVIla }\end{array}$ & $\begin{array}{l}\text { Patients with } \mathrm{HA} \\
\text { and inhibitors }\end{array}$ & 48 & $\begin{array}{l}\text { On demand: } 1 \\
\text { dose of aPCC (75- } \\
100 \mathrm{U} / \mathrm{kg} \text {; target } \\
\text { dose, } 85 \mathrm{U} / \mathrm{kg}) \text { or } 2 \\
\text { doses of rFVIla } \\
(90-120 \mu \mathrm{kg} \text {; } \\
\text { target dose, } \\
105 \mu \mathrm{g} / \mathrm{kg} \times 2) \text { IV. } \\
\text { Second dose of } \\
\text { rFVIla }\end{array}$ & NA & $\begin{array}{l}\text { Efficacy } 6 \mathrm{~h} \text { post- } \\
\text { infusion: aPCC and } \\
\text { rFVIla appear to } \\
\text { exhibit a similar ef- } \\
\text { fect on joint } \\
\text { bleeds, although } \\
\text { the efficacy be- } \\
\text { tween products is } \\
\text { rated differently by } \\
\text { a substantial pro- } \\
\text { portion of patients. }\end{array}$ \\
\hline
\end{tabular}


Table 2 (Continued)

\begin{tabular}{|c|c|c|c|c|c|c|c|}
\hline $\begin{array}{l}\text { Reference } \\
\text { (first author } \\
\text { and year) }\end{array}$ & $\begin{array}{l}\text { Study } \\
\text { name }\end{array}$ & Study design & Inclusion criteria & $N$ & Regimen/dose & $\begin{array}{l}\text { Duration of } \\
\text { treatment }\end{array}$ & Outcome \\
\hline & & & & & $\begin{array}{l}\text { administered } 2 \mathrm{~h} \\
\text { after the first dose }\end{array}$ & & $\begin{array}{l}\text { Cl for the differ- } \\
\text { ence inpercen- } \\
\text { tages of efficacy } \\
\text { reported for each } \\
\text { product only } \\
\text { slightly exceeded } \\
\text { the } 15 \% \text { boundary } \\
(-11.4 \text { to }-15.7 \%) \text {, } \\
p=0.059\end{array}$ \\
\hline $\begin{array}{l}\text { Schneider- } \\
\text { man } 2007^{125}\end{array}$ & - & $\begin{array}{l}\text { Retrospective } \\
\text { chart review }\end{array}$ & $\begin{array}{l}\text { Hospitalised chil- } \\
\text { dren aged } 18 \text { mo } \\
\text { to } 16 \text { y with severe } \\
\text { refractory haemo- } \\
\text { philia and } \\
\text { inhibitors }\end{array}$ & $\begin{array}{l}4 \text { (35 hospi- } \\
\text { tal } \\
\text { admissions) }\end{array}$ & $\begin{array}{l}\text { On demand: se- } \\
\text { quential ( } \leq 6 \mathrm{~h} \\
\text { intervals) aPCC } \\
(32-80 \mathrm{U} / \mathrm{kg}) \text { and } \\
\text { rFVIla }(103-209 \\
\mu \mathrm{g} / \mathrm{kg})\end{array}$ & - & $\begin{array}{l}\text { No clinical signs of } \\
\text { thrombosis. Reso- } \\
\text { lution of bleeds af- } \\
\text { ter a median of } 3 \mathrm{~d} \\
\text { sequential therapy }\end{array}$ \\
\hline $\begin{array}{l}\text { Ettingshau- } \\
\text { sen } 2010^{64}\end{array}$ & - & $\begin{array}{l}\text { Long-term pro- } \\
\text { spective study }\end{array}$ & $\begin{array}{l}\text { Paediatric patients } \\
(5.4-15 \text { y) with HA } \\
\text { and high-respond- } \\
\text { ing inhibitors who } \\
\text { had failed, inter- } \\
\text { rupted, or refused } \\
\text { immune tolerance } \\
\text { therapy }\end{array}$ & 7 & $\begin{array}{l}\text { Prophylaxis: aPCC } \\
50-100 \mathrm{U} / \mathrm{kg} \text {, at } \\
\text { frequencies from } \\
3 \text { times weekly up } \\
\text { to twice daily }\end{array}$ & $\begin{array}{l}0.1-1.9 \mathrm{y} \text { at start } \\
\text { of any therapy; } \\
1.5-11.8 \mathrm{y} \text { at start } \\
\text { of aPCC } \\
\text { prophylaxis }\end{array}$ & $\begin{array}{l}\text { Mean annual spon- } \\
\text { taneous joint bleed } \\
\text { incidence rate: } 1.5 \\
\text { (95\% Cl: } 0.7-3.0) \text {; } \\
\text { no or mild osteo- } \\
\text { arthropathic alter- } \\
\text { ations; no } \\
\text { thrombotic com- } \\
\text { plications, DIC or } \\
\text { viral transmission }\end{array}$ \\
\hline $\begin{array}{l}\text { Leissinger } \\
2011^{44}\end{array}$ & PRO-FEIBA & $\begin{array}{l}\text { Prospective, ran- } \\
\text { domised, cross- } \\
\text { over study }\end{array}$ & $\begin{array}{l}\text { Patients with HA } \\
>2 \text { y of age, with } \\
\text { high-titre } \\
\text { inhibitors }\end{array}$ & 26 & $\begin{array}{l}\text { Prophylaxis: } \\
85 \mathrm{U} / \mathrm{kg} \pm 15 \% \\
\text { aPCC on } 3 \text { non- } \\
\text { consecutive d/wk } \\
\text { On demand: } \\
85 \mathrm{U} / \mathrm{kg} \pm 15 \% \\
\text { aPCC }\end{array}$ & $6 \mathrm{mo}$ & $\begin{array}{l}\text { Mean } 5.0 \text { bleeding } \\
\text { events on prophy- } \\
\text { laxis vs. } 13.1 \text { with } \\
\text { on-demand treat- } \\
\text { ment; representing } \\
\text { a } 62 \% \text { reduction } \\
\text { with prophylaxis vs. } \\
\text { on-demand } \\
(p<0.001) .16 \\
(62 \%) \text { patients had } \\
\geq 50 \% \text { reduction in } \\
\text { bleeding events on } \\
\text { prophylaxis (overall } \\
84 \% \text { reduction). } \\
\text { Mean } 5.0 \text { bleeding } \\
\text { events on prophy- } \\
\text { laxis vs. } 13.1 \text { with } \\
\text { on-demand treat- } \\
\text { ment; representing } \\
\text { a } 62 \% \text { reduction } \\
\text { with prophylaxis vs. } \\
\text { on-demand ( } p \\
<0.001) .16 \text { (62\%) } \\
\text { patients had } \geq 50 \% \\
\text { reduction in bleed- } \\
\text { ing events on pro- } \\
\text { phylaxis (overall } 84 \% \\
\text { reduction) }\end{array}$ \\
\hline $\begin{array}{l}\text { Zülfikar } \\
2012^{45}\end{array}$ & - & $\begin{array}{l}\text { Multicentre regis- } \\
\text { try study in Turkey }\end{array}$ & $\begin{array}{l}\text { Patients with } \mathrm{HA} \\
\text { and inhibitors }\end{array}$ & 37 & $\begin{array}{l}\text { On demand: medi- } \\
\text { an } 50 \mathrm{U} / \mathrm{kg} \text { aPCC } \\
\text { every } 12 \mathrm{~h} \text { (acute } \\
\text { bleeds), } 100 \mathrm{U} / \mathrm{kg} \\
\text { aPCC every } 12 \mathrm{~h} \\
\text { (surgical } \\
\text { haemostasis) } \\
\text { On demand: } \\
85 \mathrm{U} / \mathrm{kg} \text { aPCC }\end{array}$ & $\begin{array}{l}\text { Median: } 2 \\
\text { infusions }\end{array}$ & $\begin{array}{l}112 \text { treatment } \\
\text { courses; } 90 \text { for } \\
\text { acute bleeds, } 22 \\
\text { for surgical hae- } \\
\text { mostasis. Consid- } \\
\text { ered success in } 92 \% \\
\text { of acute bleeds and } \\
86 \% \text { surgeries }\end{array}$ \\
\hline $\begin{array}{l}\text { Négrier } \\
2013^{47}\end{array}$ & SURF & $\begin{array}{l}\text { Open-label, non- } \\
\text { interventional, } \\
\text { post-authorisation } \\
\text { study }\end{array}$ & $\begin{array}{l}\text { Patients undergo- } \\
\text { ing surgical inter- } \\
\text { vention with aPCC }\end{array}$ & 35 & $\begin{array}{l}\text { Perioperative: } 50- \\
100 \mathrm{U} / \mathrm{kg} \text { aPCC; } \\
\text { not exceeding sin- } \\
\text { gle dose of } \\
100 \mathrm{U} / \mathrm{kg} \text { or daily } \\
\text { dose of } 200 \mathrm{U} / \mathrm{kg} \text {. } \\
50-100 \mathrm{U} / \mathrm{kg} \text { ad- } \\
\text { ministered every }\end{array}$ & Varied & $\begin{array}{l}\text { Haemostasis } \\
\text { 'good' or 'excel- } \\
\text { lent' in } 91.2 \% \text { of } \\
\text { surgical proce- } \\
\text { dures; 'fair' in } 8.8 \%\end{array}$ \\
\hline
\end{tabular}


Table 2 (Continued)

\begin{tabular}{|c|c|c|c|c|c|c|c|}
\hline $\begin{array}{l}\text { Reference } \\
\text { (first author } \\
\text { and year) }\end{array}$ & $\begin{array}{l}\text { Study } \\
\text { name }\end{array}$ & Study design & Inclusion criteria & $\mathrm{N}$ & Regimen/dose & $\begin{array}{l}\text { Duration of } \\
\text { treatment }\end{array}$ & Outcome \\
\hline & & & & & $\begin{array}{l}6-12 \mathrm{~h} \text { during or } \\
\text { after surgery }\end{array}$ & & \\
\hline $\begin{array}{l}\text { Antunes } \\
2014^{49}\end{array}$ & PROOF & $\begin{array}{l}\text { Randomised com- } \\
\text { parison of on-de- } \\
\text { mand vs. } \\
\text { prophylactic aPCC }\end{array}$ & $\begin{array}{l}\text { Patients with HA } \\
\text { or } \mathrm{HB} \text { and inhibi- } \\
\text { tors receiving } \\
\text { aPCC }\end{array}$ & 36 & $\begin{array}{l}\text { Prophylaxis: } \\
85 \pm 15 \mathrm{U} / \mathrm{kg} \text { aPCC } \\
\text { every other day. } \\
\text { On-demand: at } \\
\text { discretion of } \\
\text { investigator }\end{array}$ & $12 \mathrm{mo}$ & $\begin{array}{l}\text { Median ABR for on- } \\
\text { demand: } 28.7 ; \\
\text { prophylaxis: } 7.9 \\
\text { ( } 72.5 \% \text { reduction) }\end{array}$ \\
\hline $\begin{array}{l}\text { Ewing } \\
2015^{50}\end{array}$ & - & $\begin{array}{l}\text { Retrospective } \\
\text { chart review }\end{array}$ & $\begin{array}{l}\text { Children aged } \leq 13 \\
\text { y with severe } \mathrm{HA} \\
\text { and inhibitors re- } \\
\text { ceiving aPCC } \\
\text { prophylaxis }\end{array}$ & 16 & $\begin{array}{l}\text { Prophylaxis: } 70- \\
100 \mathrm{IU} / \mathrm{kg} \text { aPCC, } \\
3-7 \text { times weekly }\end{array}$ & $\begin{array}{l}\text { Median (range): } 9 \\
(2.6-20.5) \text { y }\end{array}$ & $\begin{array}{l}\text { AJBR reduced from } \\
4(0-48) \text { at base- } \\
\text { line to } 1(0-7) \text { after } \\
1 \text { y of prophylaxis }\end{array}$ \\
\hline $\begin{array}{l}\text { Windyga } \\
2019^{73}\end{array}$ & FEIBA GO & $\begin{array}{l}\text { Observational } \\
\text { study }\end{array}$ & $\begin{array}{l}\text { Patients with con- } \\
\text { genital HA and } \\
\text { inhibitors }\end{array}$ & 53 & $\begin{array}{l}\text { Prophylaxis: } \\
\text { median (range) } \\
61.0 \text { (50-98) U/kg } \\
\text { per infusion aPCC } \\
\text { On-demand: me- } \\
\text { dian (range) } 56.8 \\
\text { (2.3-62.5) U/kg } \\
\text { per infusion aPCC }\end{array}$ & $12 \mathrm{mo}$ & $\begin{array}{l}\text { Mean (SD) ABR for } \\
\text { patients with }>12 \\
\text { mo follow-up: pro- } \\
\text { phylaxis }(n=21) \text { : } \\
7.1(9.3) \text {; on-de- } \\
\text { mand }(n=6) \text { : } 11.4 \\
(12.8) \text {. Mean (SD) } \\
\text { AJBR: prophylaxis } \\
(n=21) \text { : } 4.2(5.1) \text {, } \\
\text { on-demand } \\
(n=6): 7.3(7.9)\end{array}$ \\
\hline
\end{tabular}

Abbreviations: ABR, annualised bleeding rate; AE, adverse event; AJBR, annualised joint bleeding rate; aPCC, activated prothrombin complex concentrate; $\mathrm{Cl}$, confidence interval; DIC, disseminated intravascular coagulation; ECMO, extracorporeal membrane oxygenation; FEIBA, factor eight inhibitor bypass activity; HA, haemophilia A; HB, haemophilia B; ITI, immune tolerance induction; IV, intravenous; NA, not applicable; PwHI, patients with haemophilia and inhibitors; rFVIla, recombinant activated factor VIla; SD, standard deviation.

bleeds before and during ITI due to the potential for anamnestic response with aPCC, owing to the presence of trace amounts of FVIII that may promote a rise in inhibitor titre. ${ }^{62}$ An anamnestic response has been reported in up to $50 \%$ of patients treated with aPCC ${ }^{50,63-65}$; nevertheless, no compromise in aPCC prophylactic efficacy has been reported, and inhibitor titres have been shown to reduce to expected levels. $^{50,63-65}$ ITI registries report successful treatment in 50 to $80 \%$ of patients with $\mathrm{HA}^{66-69}$ and in $31 \%$ of patients with HB. ${ }^{67}$ Those patients who are not successfully tolerated or not directed to ITI are usually treated with prophylactic or on-demand doses of BPAs and/or prophylactic NFTs.

The haemostatic efficacy of aPCC may be enhanced by dose optimisation, with dosage and duration of treatment being dependent on the location and extent of bleeding, the patient's clinical condition and their response. ${ }^{70}$ A clearly defined unit of potency is required for dosage calculations and clinical management. The potency designation of aPCC is expressed in arbitrary units: 1 unit of aPCC shortens the activated partial thromboplastin time (aPTT) of FVIII inhibitor-containing reference plasma by $50 \%{ }^{58}$ Due to its mechanism of action, which concludes with TG, there is risk of thrombosis. To avoid this expected $\mathrm{AE}$, the maximum daily dosage recommendation of aPCC for approved indications as monotherapy is $200 \mathrm{U} / \mathrm{kg}$ of body weight $(100 \mathrm{U} / \mathrm{kg}$ per infusion). ${ }^{27}$ However, there are no standardised assays for the monitoring of response to BPAs, and although global assays such as thromboelastography ${ }^{71}$ and TG assays ${ }^{72}$ can be useful to determine coagulation response, responses are typically evaluated by assessment of individual clinical response.

Two prospective studies assessing aPCC in the treatment of PwHI are on-going: FEIBA GO (FEIBA Global Outcome; EUPAS6691) and FEIBA STAR (FEIBA Reconstitution Volume Reduction and Faster Infusion Study; NCT02764489).

FEIBA GO is a prospective, non-interventional, multicentre cohort study in patients with HA or HB and highresponding inhibitors treated with aPCC, with a planned 4year observation period. The study aims to assess the realworld haemostatic effectiveness and safety in individuals with aPCC treatment in routine clinical practice. ${ }^{73}$ Long-term prophylactic outcome data from a real-world setting will be captured in an attempt to address the lack of data in this patient group.

FEIBA STAR is a phase $3 \mathrm{~b} / 4$, prospective, multi-centre, open-label, randomised, crossover study assessing the tolerability and safety of aPCC reconstituted in regular or $50 \%$ reduced volume and of faster infusion rates (4 and $10 \mathrm{U} / \mathrm{kg} /$ min, in comparison to the standard rate of $2 \mathrm{U} / \mathrm{kg} / \mathrm{min}$ at the regular volume) in patients with $\mathrm{HA}$ or $\mathrm{HB}$ with inhibitors. ${ }^{74}$ 
The aim of the study is to clarify if reducing infusion volumes and accelerating infusion rates for aPCC will lead to increased adherence to aPCC prophylaxis.

\section{Non-Factor Therapies}

Despite the beneficial results of BPAs, efficacy can be inconsistent, and a subset of patients on prophylactic therapy show a poor response. ${ }^{75}$ This has prompted the development of NFTs, with alternative mechanisms of action that aim to offer treatment options that are long-acting, subcutaneously administered, and efficacious irrespective of the presence of inhibitors.

To date, only one NFT - emicizumab (Hemlibra; Roche, Basel, Switzerland) - has been approved for routine prophylaxis to prevent or reduce the frequency of bleeding episodes in patients with congenital HA with (U.S. Food and Drug Administration [FDA] 10/2017, European Medicines Agency [EMA] 2/2018) or without FVIII inhibitors for HA of any severity (FDA 10/2018) or for severe HA only (EMA 3/ 2019). ${ }^{76}$ Emicizumab is a bi-specific monoclonal immunoglobulin G antibody that bridges activated FIX and FX to replace the function of missing activated FVIII, thereby enhancing coagulation and restoring haemostasis. ${ }^{77}$ With a half-life of approximately 30 days, emicizumab is suitable for once weekly, fortnightly or monthly prophylaxis, ${ }^{78}$ and has demonstrated prevention of bleeds in patients with inhibitors in clinical studies. In a phase 3 trial in adult PwHI, onceweekly emicizumab prophylaxis was associated with a lower rate of treated bleeding events compared with no prophylaxis $(2.9$ [95\% CI: $1.7-5.0]$ vs. 23.3 events [95\% CI: $12.3-$ 43.9]). ${ }^{79}$ However, limited data are available for perioperative use.

Although some case studies report the successful use of emicizumab prophylaxis in conjunction with perioperative rFVIIa, ${ }^{80-83}$ there is a lack of suitable assays for BPAs and emicizumab that allow the precise monitoring of coagulation and treatment response, necessary to guide therapy when undertaking surgical procedures. ${ }^{71,72,84,85}$ aPTT-based clotting assays, which determine FVIII activity, are not suitable for the estimation of clotting with emicizumab when used in conjunction with BPAs, because the assay is unable to reflect the combined effect on thrombin by these products, and the sensitivity of thromboelastography is currently not sufficient for guiding therapy. However, correlations between the clinical bleeding phenotype of patients and their TG capacity have been demonstrated, and as thrombin is the final product generated by combined treatment with these products, it has been proposed that the TG assay might be a more relevant test for monitoring and guiding therapy using these regimens. A three-step protocol using TG assay has been proposed to individually tailor bypassing therapy and thereby limit AEs that may occur when combining with emicizumab. ${ }^{86-89}$

A second consideration concerns the safety of the patients receiving emicizumab concomitantly with other haemostatic agents, like BPAs, for breakthrough bleeds. Despite high efficacy rates with emicizumab prophylaxis, $36 \%$ of patients still experienced breakthrough bleeds that may have required additional treatment. ${ }^{90}$ However, a potential synergistic and cumulative effect between emicizumab and aPCC is thought to exist. ${ }^{91}$ While emicizumab acts by bridging activated FIX (FIXa) and FX, allowing the coagulation cascade to continue, aPCC increases the availability of FIX/ FIXa. The combination of both agents, utilising different mechanisms of action, can result in excessive TG and increased thrombosis risk. ${ }^{91}$ In HAVEN 1, a phase 3 trial of emicizumab prophylaxis in adult PwHI, TMA was reported in three patients and TEE in two patients (cavernous sinus thrombosis and skin necrosis-superficial thrombophlebitis) who received concurrent therapy with emicizumab and aPCC for breakthrough bleeding (cumulative dose $>100 \mathrm{U} / \mathrm{kg} /$ day aPCC for more than 24 hours) ${ }^{92}$ Two of the three patients who developed TMA received both IFVIIa and aPCC (one patient received rFVIIa first then aPCC, the other patient received aPCC first then rFVIIa). The authors concluded that the TMA events were driven by the synergistic effects of high cumulative doses of aPCC in combination with emicizumab. Considering the absence of report of such AEs in this population (TMA has not previously been reported with emicizumab alone in $>5,200$ patients as of September 2019, including $>350$ patients enrolled in clinical studies as of April $2017,,^{93}$ or with aPCC alone to date ${ }^{49,58,94,95}$ ), it has been inferred that the risk of TMA is likely to arise from novel interactions between aPCC and emicizumab ${ }^{96}$ and most likely represents a mechanism distinct from the known processes leading to TMA. ${ }^{92}$ Indeed, in vitro experiments with aPCC and a sequence-identical analogue of emicizumab show elevated procoagulant activity demonstrated by excessive TG with combinations of aPCC and sequence-identical analogue of emicizumab at clinically relevant doses. ${ }^{91}$ In HAVEN 1, all TEEs occurred with concomitant aPCC and emicizumab using aPCC at doses of $>100 \mathrm{U} / \mathrm{kg} /$ day for $>24$ hours. In contrast, no events occurred with lower-dose aPCC or for treatment durations $\leq 24$ hours, which is now the recommended dose when used to treat patients receiving emicizumab..$^{93}$ In contrast to TMAs, TEEs have also been observed with emicizumab-treated patients who are not receiving aPCC. As of March 31, 2020, 18 cases of TEEs have been reported in patients receiving emicizumab in any setting (including in patients without inhibitors), two of which included concomitant use of aPCC exceeding $100 \mathrm{U} /$ $\mathrm{kg} / \mathrm{day} .{ }^{24,97}$ The use of aPCC or other haemostatic agents is unknown in the 16 additional cases. One case was reported from HAVEN 3, the phase 3 clinical trial of emicizumab for the treatment of patients with HA without inhibitors. Further clinical experience and additional research are needed to more fully elucidate the safety implications of integrating different therapies into the existing treatment landscape for PwHI.

\section{Other Therapies in Development}

Other NFTs in development are summarised in - Table 3 and include anti-tissue factor pathway inhibitors, aptamers and small interfering RNA directed against anti-thrombin III. One study points toward a benefit with concomitant use of 

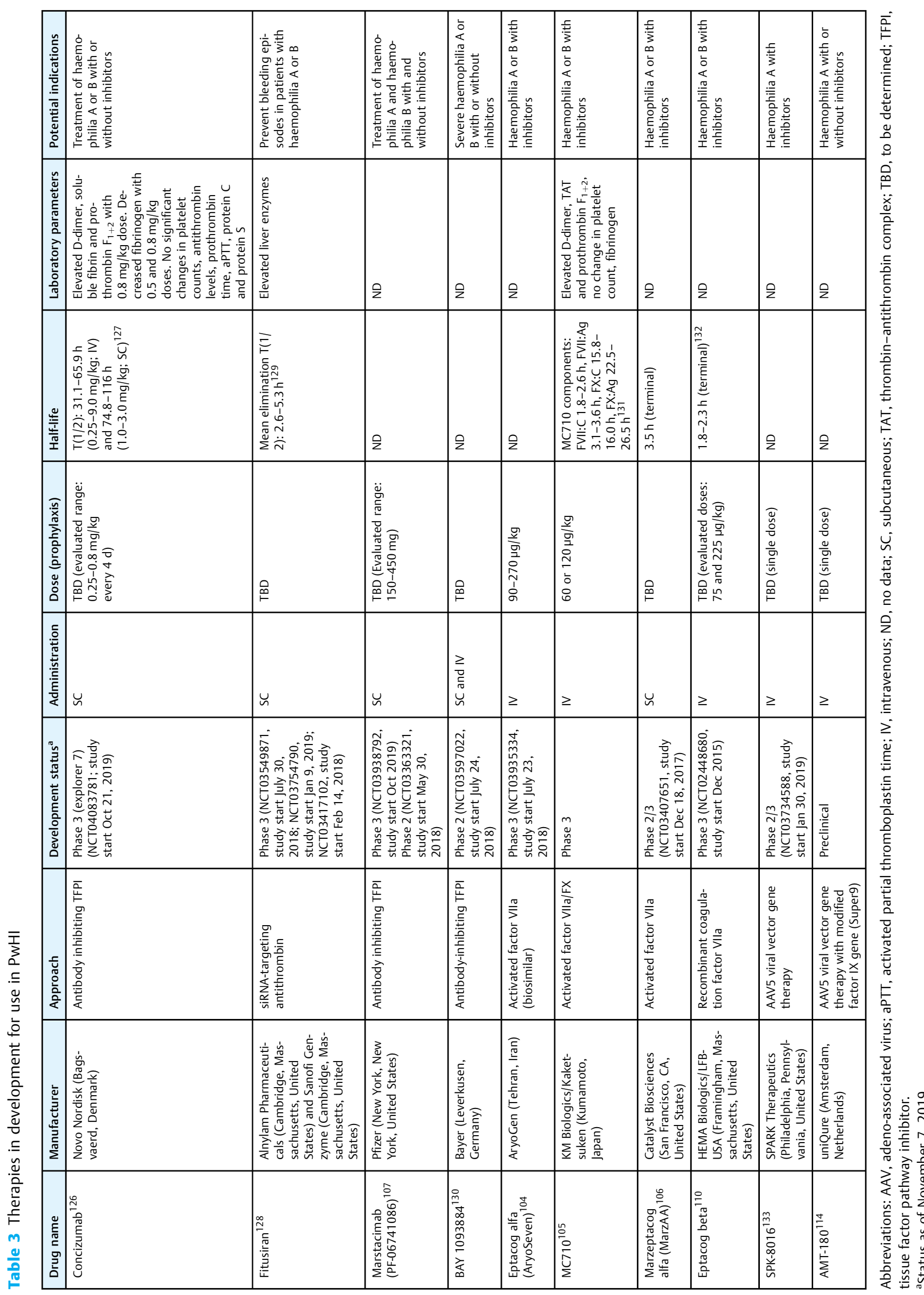
fitusiran and aPCC, with reported dosages of aPCC of 14 to $75 \mathrm{U} / \mathrm{kg}$ (13 infusions for 6 bleeds in 3 patients; mean of 2.2 infusions per bleed) and rFVIIa of 93 to $133 \mu \mathrm{g} / \mathrm{kg}$ (6 infusions for 4 bleeds in 3 patients; mean of 1.5 infusions per bleed). No complications were reported in this study, ${ }^{98}$ although a sinus vein thrombosis had occurred in a fitusiran-treated patient receiving repeated infusions of FVIII product, ${ }^{12}$ which is suggestive of similar concerns of synergistic and cumulative effects as seen with emicizumab and concomitant aPCC. In vitro and in vivo studies suggest a therapeutic benefit with concomitant concizumab and lowdose aPCC, ${ }^{99,100}$ and a synergistic haemostatic effect was reported with concomitant concizumab and rFVIIa in human blood under haemophilia conditions, ${ }^{101}$ but further data are required.

Several rFVIIa compounds are in development for PwHI ( - Table 3). An rFVIIa biosimilar protease, activated eptacog alfa (Coagil-VII; Generium), has been approved for PwHI undergoing surgery in Russia. ${ }^{102}$ However, very little clinical data have been published to date. A series of case studies with the substance reported about the experience of 10 patients given Coagil-VII after switching from NovoSeven. There were therapeutic failures in four patients and allergic reactions in two patients, for whom it was necessary to revert to NovoSeven, and a good clinical response was achieved in those patients. ${ }^{103}$ A second rFVIIa biosimilar is in development in PwHI (AryoSeven; Aryogen), with a similar response to rFVII (NovoSeven) reported in a clinical study. ${ }^{104}$

Another FVIIa product, MC710, being developed by the Chemo-Sero Therapeutic Research Institute (Japan), is a $1: 10$ protein weight ratio mixture of plasma-derived activated FVIIa and FX. ${ }^{105}$ In a phase 3, open-label study of 21 joint, muscle and subcutaneous bleeding episodes in 14 male patients, individuals received one or two doses of intravenously administered MC710 at 60 or $120 \mu \mathrm{g} / \mathrm{kg}$ once or twice (to a maximum of $180 \mu \mathrm{g} / \mathrm{kg}$ ) for up to five bleeding episodes per patient. Nineteen episode treatments were rated 'excellent' or 'effective' 8 hours after the last treatment. ${ }^{105}$

The rFVIIa variant marzeptacog alfa (MarzAA; Catalyst Biosciences) was designed to combine higher clot-generating activity and longer activity at the site of bleeding and therefore improve efficacy. ${ }^{106}$ It is anticipated that the compound could be used for both subcutaneous prophylactic treatment and intravenous acute treatment, and may be valuable for patients with $\mathrm{HB}$ with inhibitors, or patients with HA with inhibitors who failed emicizumab. ${ }^{107,108}$ The compound has achieved orphan status and is currently in phase 2 trials for patients with HA or HB with inhibitors; nine patients with high annual bleeding rates (ABRs) before the study (15.2-26.7 bleeds per year) have successfully completed long-term daily dosing with the compound. Seven participants experienced no bleeds with a $30-\mu \mathrm{g} / \mathrm{kg}$ dose and two others who escalated their dose to $60 \mu \mathrm{g} / \mathrm{kg}$ had clinically significant reductions in ABR and proportion of days with bleeding. No anti-drug antibodies were detected, but further safety data are needed. ${ }^{109}$
Eptacog beta (LR769; Hema Biologics/LFB) is a transgenic recombinant human FVIIa produced in rabbits and approved by FDA on April 1, 2020 for the treatment of bleeding episodes in HA or HB patients with inhibitors. ${ }^{110}$ In a pivotal phase 3 study of two initial dose regimens in 468 bleeding events in 27 PwHIs, both study arms met the primary endpoint of haemostatic success (evidence of cessation of bleeding). ${ }^{110}$ The majority (85\%) of the bleeding events treated with the initial $225-\mu \mathrm{g} / \mathrm{kg}$ dose required no further therapy. Currently, two additional phase 3 trials are investigating the use of eptacog beta in paediatric and surgical PwHIs. ${ }^{111}$

Encouraging results from clinical trials have also stimulated considerable interest in the application of gene therapy for the treatment of haemophilia, using in vivo gene transfer to the liver using adeno-associated viral vectors. Results from recent clinical trials suggested some therapeutic expression, and in some cases a curative effect. ${ }^{112}$ Although the presence or history of inhibitors has until recently been considered an exclusion criterion for studies with gene therapy for haemophilia, ${ }^{113}$ gene therapy trials are now underway for haemophilia patients with inhibitors. These include SPK-8016 (Spark Therapeutics), in phase $1 / 2$ development for patients with HA and inhibitors, ${ }^{114}$ and AMT-180 (uniQure), in preclinical development for patients with HA with past or current inhibitors. ${ }^{114}$

\section{Use of aPCC in PwHls in the Evolving Treatment Landscape}

As we enter an era of therapies for PwHIs with higher efficacy for prophylaxis, the use of BPAs is expected to decrease in such clinical settings. ${ }^{115}$ However, the use of aPCC is still recommended in recent treatment guidelines for haemophilia. ${ }^{3-7}$ Various scenarios in which the use of aPCC may remain necessary include (1) treatment of breakthrough bleeds or (2) as surgical prophylaxis in patients under NFT prophylaxis. Findings from the HAVEN 1 trial and the interim analysis of the STASEY study indicate that up to $37 \%$ of patients still experienced bleedings. ${ }^{31,92}$ Recent data, supported by clinical experience, indicate that aPCC $<50 \mathrm{U} / \mathrm{kg}$ is sufficient to fully restore TG and has been shown to elicit a good clinical response. ${ }^{24,85,116-119}$ (3) When following high-dose ITI regimens, such as the Bonn Protocol. For example, there are currently insufficient data to fully understand whether highdose ITI is compatible with emicizumab; therefore, until such evidence becomes available, aPCC may represent an alternative to emicizumab as prophylaxis when on an ITI regimen. (4) For treatment of acute bleeding while following an ITI protocol with addition of emicizumab, where use of aPCC (lower dose) or rFVIIa is essential. (5) Patients with HB with inhibitors, and (6) patients with acquired $\mathrm{HA},{ }^{25}$ for whom emicizumab is not indicated. $^{76}$ (7) Well-controlled patients who achieve $\geq 50 \%$ reduction in the number of bleeds ${ }^{44}$ under a current aPCC prophylaxis regimen, e.g. patients with an $A B R$ of $<4$ per year, or patients who have succeeded with ITI. (8) On-demand treatment in low income and developing countries, where access to new products may be limited ( - Table 4 ). 
Table 4 Scenarios for use of aPCC in the evolving treatment landscape

\begin{tabular}{|l|l|}
\hline 1 & $\begin{array}{l}\text { Treatment of breakthrough bleeds in patients } \\
\text { receiving NFT prophylaxis }\end{array}$ \\
\hline 2 & Surgical prophylaxis in patients receiving NFT \\
\hline 3 & Prophylaxis while on high-dose ITI \\
\hline 4 & Treatment of acute bleeds while under ITI \\
\hline 5 & Patients with haemophilia B with inhibitors \\
\hline 6 & Patients with acquired haemophilia A \\
\hline 7 & $\begin{array}{l}\text { Well-controlled patients achieving } \geq 50 \% \text { reduction } \\
\text { in bleeds with aPCC or with ABR/AJBR }<4\end{array}$ \\
\hline 8 & $\begin{array}{l}\text { On-demand treatment in low-income and developing } \\
\text { countries with limited access to treatment }\end{array}$ \\
\hline
\end{tabular}

Abbreviations: $A B R$, annualized bleeding rate; $A J B R$, annualised joint bleeding rate; aPCC, activated prothrombin complex concentrate; ITI, immune tolerance induction; NFT, non-factor therapies.

\section{Conclusions}

Since the 1970s, aPCC has been used for the treatment and prevention of acute bleeds in PwHIs and, later with rFVIIa, became standard of care. Even after more than 40 years, aPCC has a continuing role in the treatment of acute bleeds, prophylaxis, and surgical management in this patient group. Its most notable uses are for prophylaxis in patients for whom emicizumab is not available or applicable, for patients initially receiving rFVIIa who do not respond to treatment, and for low-dose treatment of breakthrough bleeds or surgery. However, there remains a need for alternative treatments for breakthrough bleeding (either spontaneous or post-trauma) and surgical applications that do not carry a risk of excess TG with concomitant usage with prophylactic treatment. As further data are generated with the newer therapeutic molecules and gene therapies for PwHI, there will be a need to identify the patient profiles that benefit most from each treatment, or combinations of treatments, for example, with the use of surrogate markers of haemostasis to enable selection of a suitable management strategy. Understanding the potential risks of unexpected AEs when integrating new therapies into the treatment armamentarium is vital, as already observed with the integration of emicizumab with aPCC. Consequently, there is a need for further exploration of potential synergistic effects between agents, of dose-ranging for the avoidance of TMA and other thrombotic risks, and for monitoring studies of combination therapies with aPCC. Considering inter-patient variability, it will be important for all haemostatic agents to remain available, with recommendations on how to use them, to ensure optimal treatment and for prevention of bleeding episodes as well as patient safety.

\section{Authors' Contributions}

All authors jointly conceived the idea for the review. All authors contributed to writing of the manuscript, and all authors critically reviewed the manuscript at each stage of development.

\section{Funding}

This study was supported by Baxalta US Inc., a Takeda company.

\section{Conflict of Interest}

Hans Hermann Brackmann has received honoraria for presentations from Takeda, Sobi and Roche. Wolfgang Schramm has participated in advisory boards for Biotest, and received honoraria for lectures from Bio\&Bio AG, Biotest, Novo, Roche and Shire, a Takeda company. Johannes Oldenburg has received grant/research support from Bayer, Biotest, CSL Behring, Novo Nordisk, Octapharma, Pfizer and Shire, a Takeda company, and fees for consultancy and speakers bureaus from Bayer, Biogen, Biotest, Chugai, CSL Behring, Grifols, Novo Nordisk, Octapharma, Pfizer, Roche, Shire, a Takeda company, and Sobi. Viridiana Cano was an employee of Shire $\mathrm{GmbH}$, a Takeda company, Zürich, Switzerland during the development of this review and a stockholder in Takeda Pharmaceutical Company Limited. Peter Turecek is an employee of Baxalta Innovations $\mathrm{GmbH}$, a Takeda company, Vienna, Austria and a stockholder in Takeda Pharmaceutical Company Limited. Claude Négrier has received grant/research support from CSL Behring, Octapharma, Shire, a Takeda company, and Sobi; fees for consultancy from Alnylam, Bayer, CSL Behring, LFB, Novo Nordisk, Octapharma, Pfizer, Roche, Shire, a Takeda company, and Sobi; and as a paid instructor for Novo Nordisk.

\section{Acknowledgements}

The authors would like to thank Berthold Semturs and Christopher Anson, Baxalta, a Takeda company, Vienna, Austria, for their assistance in compiling the source literature for this review. Under the direction of the authors, medical writing support was provided by Tina Morley, BSc, and Lindsay Napier, PhD, CMPP, employees of Excel Medical Affairs (Fairfield, Connecticut, United States) and was funded by Baxalta US Inc., a Takeda company, Lexington, Massachusetts, United States.

\section{References}

1 Bowen DJ. Haemophilia A and haemophilia B: molecular insights. Mol Pathol 2002;55(02):127-144

2 Soucie JM, Cianfrini C, Janco RL, et al. Joint range-of-motion limitations among young males with hemophilia: prevalence and risk factors. Blood 2004;103(07):2467-2473

3 Brackmann HH, Lenk H, Scharrer I, Auerswald G, Kreuz W. German recommendations for immune tolerance therapy in type A haemophiliacs with antibodies. Haemophilia 1999;5(03):203-206

4 Collins PW, Chalmers E, Hart DP, et al; UK Haemophilia Centre Doctors Organization. Diagnosis and treatment of factor VIII and IX inhibitors in congenital haemophilia: (4th edition). $\mathrm{Br} \mathrm{J}$ Haematol 2013;160(02):153-170

5 Rocino A, Coppola A, Franchini M, et al; Italian Association of Haemophilia Centres (AICE) Working Party. Principles of treatment and update of recommendations for the management of haemophilia and congenital bleeding disorders in Italy. Blood Transfus 2014;12(04):575-598 
6 Srivastava A, Brewer AK, Mauser-Bunschoten EP, et al; Treatment Guidelines Working Group on Behalf of The World Federation of Hemophilia. Guidelines for the management of hemophilia. Haemophilia 2013;19(01):e1-e47

7 Valentino LA, Kempton CL, Kruse-Jarres R, Mathew P, Meeks SL, Reiss UM; International Immune Tolerance Induction Study Investigators. US guidelines for immune tolerance induction in patients with haemophilia a and inhibitors. Haemophilia 2015; 21(05):559-567

8 Manco-Johnson MJ, Abshire TC, Shapiro AD, et al. Prophylaxis versus episodic treatment to prevent joint disease in boys with severe hemophilia. N Engl J Med 2007;357(06):535-544

9 Usuba K, Price VE, Blanchette V, et al. Impact of prophylaxis on health-related quality of life of boys with hemophilia: an analysis of pooled data from 9 countries. Res Pract Thromb Haemost 2019;3(03):397-404

10 Björkman S. Population pharmacokinetics of recombinant factor IX: implications for dose tailoring. Haemophilia 2013;19(05): 753-757

11 Björkman S, Folkesson A, Jönsson S. Pharmacokinetics and dose requirements of factor VIII over the age range 3-74 years: a population analysis based on 50 patients with long-term prophylactic treatment for haemophilia A. Eur J Clin Pharmacol 2009;65(10):989-998

12 Nogami K, Shima M. New therapies using nonfactor products for patients with hemophilia and inhibitors. Blood 2019;133(05): 399-406

13 Ehrenforth S, Kreuz W, Scharrer I, et al. Incidence of development of factor VIII and factor IX inhibitors in haemophiliacs. Lancet 1992;339(8793):594-598

14 Carcao M, Goudemand J. Inhibitors in hemophilia: a primer. 5th ed. MontrealWorld Federation of Hemophilia2018. Available at: http://www1.wfh.org/publication/files/pdf-1122.pdf. Accessed January 2, 2020

15 Chitlur M, Warrier I, Rajpurkar M, Lusher JM. Inhibitors in factor IX deficiency a report of the ISTH-SSC international FIX inhibitor registry (1997-2006). Haemophilia 2009;15(05):1027-1031

16 Ewenstein BM, Takemoto C, Warrier I, et al. Nephrotic syndrome as a complication of immune tolerance in hemophilia B. Blood 1997;89(03):1115-1116

17 Astermark J. Inhibitor development: patient-determined risk factors. Haemophilia 2010;16(102):66-70

18 Astermark J, Altisent C, Batorova A, et al; European Haemophilia Therapy Standardisation Board. Non-genetic risk factors and the development of inhibitors in haemophilia: a comprehensive review and consensus report. Haemophilia 2010;16(05):747-766

19 Gouw SC, Fijnvandraat K. Identifying nongenetic risk factors for inhibitor development in severe hemophilia a. SeminThrombHemost 2013;39(07):740-751

20 Kempton CL, White GC II. How we treat a hemophilia A patient with a factor VIII inhibitor. Blood 2009;113(01):11-17

21 Rocino A, Franchini M, Coppola A. Treatment and prevention of bleeds in haemophilia patients with inhibitors to factor VIII/IX. J Clin Med 2017;6(04):E46

22 Eckhardt CL, Loomans JI, van Velzen AS, et al; INSIGHT Study Group. Inhibitor development and mortality in non-severe hemophilia A. J ThrombHaemost 2015;13(07):1217-1225

23 Walsh CE, Soucie JM, Miller CH; United States Hemophilia Treatment Center Network. Impact of inhibitors on hemophilia A mortality in the United States. Am J Hematol 2015;90(05): 400-405

24 National Hemophilia Foundation. Recommendation on the use and management of emicizumabKXWH (Hemlibra(r)) for hemophilia A with and without inhibitors. Available at: https://www. hemophilia.org/sites/default/files/document/files/258_emicizumab.pdf. Published 2020. Accessed May 12, 2020

25 Carcao M, Escuriola-Ettingshausen C, Santagostino E, et al; Future of Immunotolerance Treatment Group. The changing face of immune tolerance induction in haemophilia A with the advent of emicizumab. Haemophilia 2019;25(04):676-684

26 Kempton CL, Meeks SL. Toward optimal therapy for inhibitors in hemophilia. Blood 2014;124(23):3365-3372

27 Shire Pharmaceuticals Limited. FEIBA summary of product characteristics. Available at: https://www.medicines.org.uk/ emc/product/9192/smpc. Published 2019. Updated January 24, 2019. Accessed January 2, 2020

28 Négrier C, Voisin S, Baghaei F, et al; FEIBA PASS Study group. Global Post-Authorization Safety Surveillance Study: real-world data on prophylaxis and on-demand treatment using FEIBA (an activated prothrombin complex concentrate). Blood Coagul Fibrinolysis 2016;27(05):551-556

29 Novo Nordisk Limited. NovoSeven $1 \mathrm{mg}$ (50KIU) powder and solvent for solution for injection: Summary of Product Characteristics. Available at: https://www.medicines.org.uk/emc/product/6360/ smpc\#DOCREVISION. Published 2018. Accessed January 2, 2020

30 Matino D, Makris M, Dwan K, D'Amico R, Iorio A. Recombinant factor VIIa concentrate versus plasma-derived concentrates for treating acute bleeding episodes in people with haemophilia and inhibitors. Cochrane Database Syst Rev 2015;(12):CD004449

31 Astermark J, Donfield SM, DiMichele DM, et al; FENOC Study Group. A randomized comparison of bypassing agents in hemophilia complicated by an inhibitor: the FEIBA NovoSeven Comparative (FENOC) Study. Blood 2007;109(02):546-551

32 Breen FAJ Jr, Tullis JL. Prothrombin concentrates in treatment of Christmas disease and allied disorders. JAMA 1969;208(10): 1848-1852

33 DeWitt RT, Feinstein DI. Prothrombin complex concentrate. Arch Intern Med 1977;137(09):1211-1213

34 Kurczynski EM, Penner JA. Activated prothrombin concentrate for patients with factor VIII inhibitors. N Engl J Med 1974;291 (04):164-167

35 Sultan Y, Brouet JC, Debre P. Letter: Treatment of inhibitors to factor VIII with activated prothrombin concentrate. N Engl J Med 1974;291(20):1087

36 Kelly P, Penner JA. Antihemophilic factor inhibitors. Management with prothrombin complex concentrates. JAMA 1976;236 (18):2061-2064

37 Prowse CV. Activated prothrombin complex concentrates: approaches to their preparation. Thromb Res 1982;25(03):213-218

38 Turecek PL, Váradi K, Schwarz HP. Update on the mechanism of action and future of activated prothrombin complex concentrates. CurrHematol Rep 2004;3(05):331-337

39 Négrier C, Gomperts ED, Oldenburg J. The history of FEIBA: a lifetime of success in the treatment of haemophilia complicated by an inhibitor. Haemophilia 2006;12(S5):4-13

40 Shire. FEIBA (anti-inhibitor coagulant complex) for intravenous use, lyophilized powder for solution [Prescribing Information]. Available at: https://www.shirecontent.com/PI/PDFs/FEIBA_USA_ENG.pdf. Published January 1, 2019. Accessed January 2, 2020

41 Varadi K, Tangada S, Loeschberger M, et al. Pro- and anticoagulant factors facilitate thrombin generation and balance the haemostatic response to $\operatorname{FEIBA}\left({ }^{\circledR}\right)$ in prophylactic therapy. Haemophilia 2016;22(04):615-624

42 Turecek PL, Váradi K, Gritsch H, Schwarz HP. FEIBA: mode of action. Haemophilia 2004;10(Suppl 2):3-9

43 Hilgartner MW, Knatterud GL. The use of factor eight inhibitor by-passing activity (FEIBA immuno) product for treatment of bleeding episodes in hemophiliacs with inhibitors. Blood 1983; 61(01):36-40

44 Leissinger C, Gringeri A, Antmen B, et al. Anti-inhibitor coagulant complex prophylaxis in hemophilia with inhibitors. N Engl J Med 2011;365(18):1684-1692

45 Zülfikar B, Aydogan G, Salcioglu Z, et al; FEIBA Investigators Team. Efficacy of FEIBA for acute bleeding and surgical haemostasis in haemophilia A patients with inhibitors: a multicentre registry in Turkey. Haemophilia 2012;18(03):383-391 
46 DiMichele D. Inhibitor development in haemophilia B: an orphan disease in need of attention. Br J Haematol 2007;138(03): 305-315

47 Négrier C, Lienhart A, Numerof R, et al. SURgical interventions with FEIBA (SURF): international registry of surgery in haemophilia patients with inhibitory antibodies. Haemophilia 2013;19 (03): $143-\mathrm{e} 150$

48 Dimichele D, Négrier C. A retrospective postlicensure survey of FEIBA efficacy and safety. Haemophilia 2006;12(04):352-362

49 Antunes SV, Tangada S, Stasyshyn O, et al. Randomized comparison of prophylaxis and on-demand regimens with FEIBA NF in the treatment of haemophilia A and B with inhibitors. Haemophilia 2014;20(01):65-72

50 Ewing N, Escuriola-Ettingshausen C, Kreuz W. Prophylaxis with FEIBA in paediatric patients with haemophilia $A$ and inhibitors. Haemophilia 2015;21(03):358-364

51 Nakar C, Manco-Johnson MJ, Lail A, et al. Prompt immune tolerance induction at inhibitor diagnosis regardless of titre may increase overall success in haemophilia A complicated by inhibitors: experience of two U.S. centres. Haemophilia 2015;21 (03):365-373

52 Oldenburg J, Schwaab R, Brackmann HH. Induction of immune tolerance in haemophilia A inhibitor patients by the 'Bonn Protocol': predictive parameter for therapy duration and outcome. Vox Sang 1999;77(01, Suppl 1):49-54

53 Brackmann HH, Gormsen J. Massive factor-VIII infusion in haemophiliac with factor-VIII inhibitor, high responder. Lancet 1977;2(8044):933

54 Brackmann HH, Oldenburg J, Schwaab R. Immune tolerance for the treatment of factor VIII inhibitors-twenty years' 'bonn protocol'. Vox Sang 1996;70(Suppl 1):30-35

55 Brackmann HH. Induced immunotolerance in factor VIII inhibitor patients. ProgClinBiol Res 1984;150:181-195

56 Zeitler H, Ulrich-Merzenich G, Hess L, et al. Treatment of acquired hemophilia by the Bonn-Malmo Protocol: documentation of an in vivo immunomodulating concept. Blood 2005;105 (06):2287-2293

57 Rota M, Cortesi PA, Crea R, Gringeri A, Mantovani LG. Thromboembolic event rate in patients exposed to anti-inhibitor coagulant complex: a meta-analysis of 40-year published data. Blood Adv 2017;1(26):2637-2642

58 Luu $\mathrm{H}$, Ewenstein B. FEIBA safety profile in multiple modes of clinical and home-therapy application. Haemophilia 2004;10 (Suppl 2):10-16

59 duTreil S. Physical and psychosocial challenges in adult hemophilia patients with inhibitors. J Blood Med 2014;5:115-122

60 Waters B, Lillicrap D. The molecular mechanisms of immunomodulation and tolerance induction to factor VIII.J ThrombHaemost 2009;7(09):1446-1456

61 Kim YC, Zhang AH, Su Y, et al. Engineered antigen-specific human regulatory T cells: immunosuppression of FVIII-specific T- and Bcell responses. Blood 2015;125(07):1107-1115

62 Giangrande PLF, Hermans C, O'Mahony B, et al; European Haemophilia Consortium (EHC) and the European Association for Haemophilia and Allied Disorders (EAHAD). European principles of inhibitor management in patients with haemophilia. Orphanet J Rare Dis 2018;13(01):66

63 Négrier C, Goudemand J, Sultan Y, Bertrand M, Rothschild C, Lauroua P. Multicenter retrospective study on the utilization of FEIBA in France in patients with factor VIII and factor IX inhibitors. French FEIBA Study Group. Factor Eight Bypassing Activity. ThrombHaemost 1997;77(06):1113-1119

64 Ettingshausen CE, Kreuz W. Early long-term FEIBA prophylaxis in haemophilia A patients with inhibitor after failing immune tolerance induction: a prospective clinical case series. Haemophilia 2010;16(01):90-100

65 Zanon E, Pasca S, Santoro C, et al. Activated prothrombin complex concentrate $\left(\right.$ FEIBA $\left.^{\circledR}\right)$ in acquired haemophilia A: a large multi- centre Italian study - the FAIR Registry. Br J Haematol 2019;184 (05):853-855

66 Coppola A, Margaglione M, Santagostino E, et al; AICE PROFIT Study Group. Factor VIII gene (F8) mutations as predictors of outcome in immune tolerance induction of hemophilia A patients with high-responding inhibitors. J ThrombHaemost 2009;7(11):1809-1815

67 DiMichele DM, Kroner BL; North American Immune Tolerance Study Group. The North American Immune Tolerance Registry: practices, outcomes, outcome predictors. ThrombHaemost 2002;87(01):52-57

68 Lenk H; ITT Study Group. The German Registry of immune tolerance treatment in hemophilia-1999 update. Haematologica 2000;85(10, Suppl):45-47

69 Mariani G, Kroner B; Immune Tolerance Study Group (ITSG). Immune tolerance in hemophilia with factor VIII inhibitors: predictors of success. Haematologica 2001;86(11):1186-1193

70 Shapiro AD, Hedner U. Advances in bypassing agent therapy for hemophilia patients with inhibitors to close care gaps and improve outcomes. Ther Adv Drug Saf 2011;2(05):213-225

71 Sørensen B, Ingerslev J. Tailoring haemostatic treatment to patient requirements - an update on monitoring haemostatic response using thrombelastography. Haemophilia 2005;11 (Suppl 1):1-6

72 Váradi K, Négrier C, Berntorp E, et al. Monitoring the bioavailability of FEIBA with a thrombin generation assay. J ThrombHaemost 2003;1(11):2374-2380

73 Windyga J, Holme P, Hermans C, et al. Real world clinical management of patients with hemophilia and inhibitors: effectiveness and safety of aPCC in patients with $>18$ months' followup in the FEIBA Global Outcome study (FEIBA GO). Blood 2019; 134(S1):2418

74 Ali TMCR, Wanek K, Cano V. Tolerability/safety of FEIBA reconstituted in regular or $50 \%$ reduced volume and faster infusion rates: rationale and study design in patients with hemophilia $\mathrm{A}$ or B with inhibitors. Haemophilia 2018;24(S1):119

75 Berntorp E. Differential response to bypassing agents complicates treatment in patients with haemophilia and inhibitors. Haemophilia 2009;15(01):3-10

76 Genentech Inc. Hemlibra (emicizumab-kxwh) injection for subcutaneous use [Prescribing Information]. Available at: https:// www.accessdata.fda.gov/drugsatfda_docs/label/2017/ 761083s000lbl.pdf. Published November 2017. Accessed January 2, 2020

77 Mahlangu J, Oldenburg J, Paz-Priel I, et al. Emicizumab prophylaxis in patients who have hemophilia A without inhibitors. $\mathrm{N}$ Engl J Med 2018;379(09):811-822

78 Callaghan MU, Sidonio R, Pipe SW. Novel therapeutics for hemophilia and other bleeding disorders. Blood 2018;132(01): 23-30

79 Oldenburg J, Mahlangu JN, Kim B, et al. Emicizumab prophylaxis in hemophilia A with inhibitors. N Engl J Med 2017;377(09): 809-818

80 Seaman CD, Ragni MV. Emicizumab use in major orthopedic surgery. Blood Adv 2019;3(11):1722-1724

81 Santagostino E, Mancuso ME, Novembrino C, Solimeno LP, Tripodi A, Peyvandi F. Rescue factor VIII replacement to secure hemostasis in a patient with hemophilia $\mathrm{A}$ and inhibitors on emicizumab prophylaxis undergoing hip replacement. Haematologica 2019;104(08):e380-e382

82 Zimowski K, Batsuli GM, Reding MT, et al. Maintaining perioperative hemostasis in patients with severe hemophilia $A$ and inhibitors receiving emicizumab prophylaxis. Blood 2018; 132:635

83 Kruse-Jarres R, Callaghan MU, Croteau SE, et al. Surgical experience in two multicenter, open-label phase 3 studies of emicizumab in persons with hemophilia A with inhibitors (HAVEN 1 and HAVEN 2). Blood 2017;130:89 
84 Brophy DF, Martin EJ, Kuhn J. Use of global assays to monitor emicizumab prophylactic therapy in patients with haemophilia A with inhibitors. Haemophilia 2019;25(02):e121-e123

85 Dargaud Y, Lienhart A, Janbain M, Le Quellec S, Enjolras N, Négrier $C$. Use of thrombin generation assay to personalize treatment of breakthrough bleeds in a patient with hemophilia and inhibitors receiving prophylaxis with emicizumab. Haematologica 2018;103(04):e181-e183

86 Dargaud Y, Lienhart A, Négrier C. Prospective assessment of thrombin generation test for dose monitoring of bypassing therapy in hemophilia patients with inhibitors undergoing elective surgery. Blood 2010;116(25):5734-5737

87 van Veen JJ, Gatt A, Bowyer AE, Cooper PC, Kitchen S, Makris M. The effect of tissue factor concentration on calibrated automated thrombography in the presence of inhibitor bypass agents. Int J Lab Hematol 2009;31(02):189-198

88 Luna-Záizar H, Beltrán-Miranda CP, Esparza-Flores MA, et al. Thrombin generation as objective parameter of treatment response in patients with severe haemophilia $A$ and high-titre inhibitors. Haemophilia 2014;20(01):e7-e14

89 Turecek PL, Váradi K, Keil B, et al. Factor VIII inhibitor-bypassing agents act by inducing thrombin generation and can be monitored by a thrombin generation assay. PathophysiolHaemostThromb 2003;33(01):16-22

90 Jiménez-Yuste V, Klamroth R, Castaman G, et al. A single-arm, multicentre, open-label, phase III clinical trial to evaluate the safety and tolerability of prophylactic emicizumab in persons with haemophilia A (PwHA) with FVIII inhibitors (STASEY): interim analysis results. Res Pract Thromb Haemost 2019;3 (S1):116-117

91 Hartmann R, Feenstra T, Valentino L, Dockal M, Scheiflinger F. In vitro studies show synergistic effects of a procoagulant bispecific antibody and bypassing agents. J Thromb Haemost 2018; 16:1580-1591

92 Oldenburg J, Levy GG. Emicizumab prophylaxis in hemophilia A with inhibitors. N Engl J Med 2017;377(22):2194-2195

93 Tiede A. Thromboembolic risks of non-factor replacement therapies in hemophilia. Hamostaseologie 2017;37(04):307-310

94 Dimichele D, Négrier C. A retrospective postlicensure survey of FEIBA efficacy and safety. Haemophilia 2006;12(04):352-362

95 Mahlangu J, Oldenburg J, Callaghan MU, et al. Bleeding events and safety outcomes in persons with haemophilia A with inhibitors: A prospective, multi-centre, non-interventional study. Haemophilia 2018;24(06):921-929

96 Aledort LM, Ewenstein BM. Emicizumab Prophylaxis in Hemophilia A with Inhibitors. N Engl J Med 2017;377(22):2193

97 Genentech. Hemlibra. Serious Thrombotic Events. Available at: https://www.emicizumabinfo.com/content/dam/gene/emicizumabinfo/hcp/pdfs/serious_thrombotic_events.pdf. Published 2020. Accessed May 12, 2020

98 Rangarajan SGP, Mant T, Creagh MD, et al. Management of bleed events in the phase I study of fitusiran, an investigational RNA therapeutic targeting antithrombin for the treatment of hemophilia in patients with and without inhibitors. Haemophilia 2017;23(S2): 10

99 Fernandez-Bello I, Alvarez-Roman M, Martin-Salces M, et al. Thromboelastography may be useful for tailoring treatment of breakthrough bleeds in patients on prophylaxis with Concizumab. Haemophilia 2019;25(S1):107-108

100 Augustsson C, Kjelgaard-Hansen M, Lind V, Hilden I. In vitro activity of concizumab in combination with activated prothrombin complex concentrate or rFVIIa as studied by thromboelastography and thrombin generation. Haemophilia 2018;24 (S5):43

101 Lauritzen B, Olling J, Abel KL, et al. Administration of recombinant FVIIa (rFVIIa) to concizumab-dosed monkeys is safe, and concizumab does not affect the potency of rFVIIa in hemophilic rabbits. J Thromb Haemost 2019;17(03):460-469
102 Shiller EPV, Svirin P, Vdovin V, et al. Long-term prophylaxis with activated recombinant FVII in children with hemophilia A and inhibitor, receiving treatment with ITI protocol. Blood 2016; 128:4980

103 Andreeva TA, Konstantinova VN. Adverse reactions using biosimilar of rFVIIa Coagil VII. 18th International Meeting Danubian League against Thrombosis and Haemorrhagic Disorders, Sarajevo, May 14-16, 2015. Available at: https://bib.irb.hr/ datoteka/819844.DLTH-Abstract-Book-Sarajevo-2015.pdf. Published 2015. Accessed January 2, 2020

104 Faranoush M, Abolghasemi H, Mahboudi F, et al. A comparison of efficacy between recombinant activated factor VII (Aryoseven) and novoseven in patients with hereditary FVIII deficiency with inhibitor. Clin Appl Thromb Hemost 2016;22(02): 184-190

105 Shinkoda Y, Shirahata A, Fukutake K, et al. A phase III clinical trial of a mixture agent of plasma-derived factor VIIa and factor X (MC710) in haemophilia patients with inhibitors. Haemophilia 2017;23(01):59-66

106 Catalyst Biosciences. Factor VIIa marzeptacog alfa (activated). Available at: https://www.globenewswire.com/news-release/ 2018/09/04/1564830/0/en/Catalyst-Biosciences-AnnouncesPublication-of-Marzeptacog-Alfa-Activated-Phase-1-Data-inThe-Journal-of-Thrombosis-and-Haemostasis.html. Published 2019. Accessed January 2, 2020

107 Mahlangu J, Lamas JL, Morales JC, et al. A phase $1 \mathrm{~b} / 2$ study of the safety, tolerability, pharmacokinetics, pharmacodynamics, and efficacy of PF-06741086, an anti-TFPI monoclonal antibody, in patients with severe hemophilia A or B. Res PractThrombHaemost 2019;3(S1):85-86

108 Gruppo RA, Malan D, Kapocsi J, et al; Marzeptacog alfa (activated) Study Group Investigators. Phase 1, single-dose escalating study of marzeptacog alfa (activated), a recombinant factor VIIa variant, in patients with severe hemophilia. J ThrombHaemost 2018;16(10):1984-1993

109 Mahlangu J, Levy $\mathrm{H}$, Khacchatryan $\mathrm{H}$, et al. Phase $2 / 3$ trial of subcutaneous engineered FVII a marzeptacoga Lfa (activated) in hemophilia A or B with inhibitors: efficacy, safety and pharmacokinetics. Res Pract Thromb Haemost 2019;3(S1):86-87

110 PR Newswire. HEMA Biologics, LLC announced today the acceptance by U.S. Food and Drug Administration of the submitted biologic license application for coagulation factor VIIa recombinant (eptacog beta activated). Available at: https://www. prnewswire.com/news-releases/hema-biologics-llc-announced-today-the-acceptance-by-us-food-and-drug-administration-of-the-submitted-biologic-license-application-for-coagulation-factor-viia-recombinant-eptacog-beta-activated300387578.html. Published 2017. Accessed January 2, 2020

111 Hema Biologics. Pipeline. Available at: https://hemabio.com/ pipeline/. Published 2019. Accessed January 2, 2020

112 George LA. Hemophilia gene therapy comes of age. Hematology (Am Soc Hematol Educ Program) 2017;2017(01):587-594

113 Yamaguti-Hayakawa GG, Ozelo MC. Gene therapy: paving new roads in the treatment of hemophilia. Semin Thromb Hemost 2019;45(07):743-750

114 UniQure. Gene therapy: hemophilia. Available at: http://www. uniqure.com/gene-therapy/hemophilia.php. Published 2019. Accessed January 2, 2020

115 Shapiro AD, Mitchell IS, Nasr S. The future of bypassing agents for hemophilia with inhibitors in the era of novel agents. J Thromb Haemost 2018;16(12):2362-2374

116 Susen S, Gruel Y, Godier A, et al. Management of bleeding and invasive procedures in haemophilia A patients with inhibitor treated with emicizumab $\left(\mathrm{Hemlibra}^{\circledR}{ }^{\circledR}\right.$ ): proposals from the French network on inherited bleeding disorders (MHEMO), the French Reference Centre on Haemophilia, in collaboration with the French Working Group on Perioperative Haemostasis (GIHP). Haemophilia 2019;25(05):731-737 
117 Collins PW, Liesner R, Makris M, et al. Treatment of bleeding episodes in haemophilia A complicated by a factor VIII inhibitor in patients receiving Emicizumab. Interim guidance from UKHCDO Inhibitor Working Party and Executive Committee. Haemophilia 2018;24(03):344-347

118 Ljung R, Auerswald G, Benson G, et al. Inhibitors in haemophilia A and $\mathrm{B}$ : management of bleeds, inhibitor eradication and strategies for difficult-to-treat patients. Eur J Haematol 2019;102(02):111-122

119 Young G. How I treat children with haemophilia and inhibitors. Br J Haematol 2019;186(03):400-408

120 Sjamsoedin LJ, Heijnen L, Mauser-Bunschoten EP, et al. The effect of activated prothrombin-complex concentrate (FEIBA) on joint and muscle bleeding in patients with hemophilia $A$ and antibodies to factor VIII. A double-blind clinical trial. N Engl J Med 1981; 305(13):717-721

121 Hilgartner M, Aledort L, Andes A, Gill J; FEIBA Study Group. Efficacy and safety of vapor-heated anti-inhibitor coagulant complex in hemophilia patients. Transfusion 1990;30(07):626-630

122 Ehrlich HJ, Henzl MJ, Gomperts ED. Safety of factor VIII inhibitor bypass activity (FEIBA): 10-year compilation of thrombotic adverse events. Haemophilia 2002;8(02):83-90

123 Bui JD, Despotis GD, Trulock EP, Patterson GA, Goodnough LT. Fatal thrombosis after administration of activated prothrombin complex concentrates in a patient supported by extracorporeal membrane oxygenation who had received activated recombinant factor VII. J Thorac Cardiovasc Surg 2002;124(04):852-854

124 Rosenfeld SB, Watkinson KK, Thompson BH, Macfarlane DE, Lentz SR. Pulmonary embolism after sequential use of recombinant factor VIIa and activated prothrombin complex concentrate in a factor VIII inhibitor patient. Thromb Haemost 2002;87(05): 925-926

125 Schneiderman J, Rubin E, Nugent DJ, Young G. Sequential therapy with activated prothrombin complex concentrates and recom- binant FVIIa in patients with severe haemophilia and inhibitors: update of our previous experience. Haemophilia 2007;13(03): 244-248

126 Eichler H, Angchaisuksiri P, Kavakli K, et al. A randomized trial of safety, pharmacokinetics and pharmacodynamics of concizumab in people with hemophilia A. J ThrombHaemost 2018;16 (11):2184-2195

127 Chowdary P, Lethagen S, Friedrich U, et al. Safety and pharmacokinetics of anti-TFPI antibody (concizumab) in healthy volunteers and patients with hemophilia: a randomized first human dose trial. J Thromb Haemost 2015;13(05):743-754

128 Sehgal A, Barros S, Ivanciu L, et al. An RNAi therapeutic targeting antithrombin to rebalance the coagulation system and promote hemostasis in hemophilia. Nat Med 2015;21(05):492-497

129 Pasi KJ, Rangarajan S, Georgiev P, et al. Targeting of antithrombin in hemophilia A or B with RNAi therapy. N Engl J Med 2017;377 (09):819-828

$130 \mathrm{Gu}$ JM, Zhao XY, Schwarz T, et al. Mechanistic modeling of the pharmacodynamic and pharmacokinetic relationship of tissue factor pathway inhibitor-neutralizing antibody (BAY 1093884) in cynomolgus monkeys. AAPS J 2017;19(04):1186-1195

131 Shirahata A, Fukutake K, Takamatsu J, et al. A Phase II clinical trial of a mixture of plasma-derived factor VIIa and factor X (MC710) in haemophilia patients with inhibitors: haemostatic efficacy, safety and pharmacokinetics/pharmacodynamics. Haemophilia 2013;19(06):853-860

132 Ducore J, Lawrence JB, Simpson M, et al. Safety and dosedependency of eptacog beta (activated) in a dose escalation study of non-bleeding congenital haemophilia A or B patients, with or without inhibitors. Haemophilia 2017;23(06):844-851

133 Spark Therapeutics. Pipeline. Available at: http://sparktx.com/scientific-platform-programs/. Published 2019. Accessed January 2, 2020 